\title{
Prevalence of hypertension among adolescents
}

\author{
Pranam G $M^{1}$, Usha Pranam $G^{2}$, Manjunath G $A^{3}$ \\ ${ }^{1}$ Dr Pranam GM, Assistant Professor, ${ }^{2}$ Dr Usha Pranam, Assistant Professor, ${ }^{3}$ Dr Manjunath G A, Professor, All are \\ affiliated with are Department of Pediatrics, Navodaya Medical College, Raichur, Karnataka, India
}

Address of correspondence: Dr Usha Pranam, c/o Dr G A Manjunath, H.No 5, Bheemaraya Colony, Yeramarus Camp, Raichur, Email id : drushagowdar@ rediffmail.com

\begin{abstract}
Introduction: Adolescence is a significant period of growth and maturation. The emergence of obesity and its sequel as public health problems has renewed interest in the adolescents as Overweight and obesity act as risk factors for obesity related diseases. Familial aggregation of blood pressure is noted among adults, which has been traced to childhood, as early as one year of age. Methods: a cross sectional study involving 1000 boys and girls each were subjected to measurement of anthropometry, blood pressure and BMI. Results: The Incidence of Raised Blood Pressure in our study was $1.3 \%$. The mean systolic blood pressure in boys increased from $102.75 \pm 3.24 \mathrm{mmHg}$ at 12 years of age to $105.85 \pm 3.58$ $\mathrm{mmHg}$ at 16years. In girls it rises from $102.04 \pm 2.53 \mathrm{mmHg}$ at 12 years to $106.48 \pm 3.59 \mathrm{mmHg}$ at 16 years. The mean diastolic blood pressure increased from $66.85 \pm 3.45 \mathrm{mmHg}$ at 12 years of age to $67.95 \pm 4.24 \mathrm{mmHg}$ at $16 y$ ears, in boys. In girls it rises from $66.90 \pm 3.38 \mathrm{mmHg}$ at 12 years to $68.95 \pm 4.53 \mathrm{mmHg}$ at 16years. Blood pressure recordings showed an increasing trend steadily with age in the present study. Conclusion: There is a strong correlation between systolic blood pressure and weight and height in both sexes. Majority of the children who were labeled as hypertensive's are likely to be suffering from essential hypertension, because of the asymptomatic nature of their condition. Hence the adolescent period the most precious stage for early detection and primary prevention on hypertension.
\end{abstract}

Keywords: Mean Blood Pressure, Hypertension. Adolescents, BMI

\section{Introduction}

Adolescence is a significant period of growth and maturation, unique changes occur and many adult patterns are established during this period. Proximity to biological maturity may provide final opportunities for preventing health problems [1]. It has often failed to receive the attention given to earlier periods in childhood with regards to health related issues and interpretation of anthropometry [2]. Most nutrition research in the developing world focused on undernutrition in under-five children. Studies [3, 4] have shown that many of the developing countries including India are facing the dual burden of under-nutrition and over-nutrition. Data from National Family Health Survey 2 (NFHS 2) [5] has identified that significant proportion of over-weight coexists with high rates of malnutrition, pointing that the nutrition transition is underway in India.

Manuscript received: $24^{\text {th }}$ Oct 2015

Reviewed: $4^{\text {th }}$ Nov 2015

Author Corrected: $15^{\text {th }}$ Nov 2015

Accepted for Publication: 23th Nov 2015
The emergence of obesity and its sequel as public health problems has renewed interest in the adolescent anthropometry. Overweight and obesity during this period are associated with risk factors for obesity related diseases [6, 7]. The WHO Expert Committee [8] has recommended that measures of height and weight provide useful source of data for assessment of growth status of adolescents.

The prevalence of hypertension, and its associated complications has reached such an enormous proportion, that World Health Organization has recognized it and expressed its concern about it by observing the year 1978 with the slogan "Down with Blood Pressure". In the past decade, many workers have confirmed that familial aggregation of blood pressure occurs among adults, and such an aggregation, has been traced to childhood, as early as one year of age and there is some evidence to believe that such an aggregation begins somewhere between first week and first month of life [9]. 
Although the natural history of essential hypertension, in the young is not clear, there is not great reason to be optimistic that it is significantly better than in adults. One of the challenges, therefore, is to try to develop means for identifying youngsters at high risk for later sustained hypertension and to prevent it [10].

Essential hypertension, a major risk factor for cardiovascular disease is prevalent in the adult population. A prevalence of $18 \%$ has been reported from Iran. Blood pressure in children is a reliable predictor of adult blood pressure level, therefore it is important to identify children and adolescence who are at increased risk of developing essential hypertension as adults.

Hurst, in his textbook 'The Heart', says that the diagnosis of hypertension in pediatric patients is truly population based, since $5 \%$ of children with highest blood pressure are diagnosed with "significant hypertension" and highest $1 \%$ are deemed eligible for pharmacological treatment [11].

Obviously this is a job to be taken up by the pediatricians. It is being increasingly recognized that essential hypertension in adult does not appear suddenly beyond the age of 30 years. Children with upper percentile of blood pressure levels are more likely to become adult hypertensive. If the trend towards adult hypertension can be recognized in childhood, it may be possible to alter life style and prevent systemic hypertension as well as related complications [12].

Ideally hypertension or tendency for hypertension should be detected as early in life as possible. According to Nelson, to increase early detection of hypertension, accurate blood pressure measurements should be part of the routine annual physical, examination of all children, three years or older [13].

However it is not possible to record reliable blood pressures by conventional methods in children below 67 years of age [14]. Hence the ideal age, would be between 6-15 years, i.e. school children. This recognition has made the medical workers and authorities in Western countries to include routine blood pressure measurements in school health programmes and in regular office practice. NIH Task force of USA has even recommended that blood pressure measurements along with weight and height should be recorded in children, at least once a year $[15,16]$, But even today in many parts of the world including India, this practice has not been implemented due to unknown reasons.

The present study was conducted in Raichur both rural and urban area to evaluate the anthropometric profile and blood pressure in apparently healthy children of 1216 years of age group.

\section{Materials and Methods}

The study group comprised of 1000 boys and girls each of ages between 12 to 16 years. Informed consent was obtained from the guardian and a detailed questionnaire was filled. All the subjects underwent measurement of height, weight, four skin fold thickness and Blood pressure, from which the BMI and body fat composition was calculated. BMI was calculated by the standard formula.

The data thus collected was tabulated according to various epidemiological parameters. The mean values and standard deviation of all Anthropometric parameters were calculated. T-test, unpaired, was used to find the difference between the mean values among boys and girls concerned with systolic blood pressure, diastolic blood pressure, height and weight. The Pearson's or product moment correlation coefficients (r) were calculated between weight and systolic blood pressure, weight and diastolic blood pressure, height and systolic blood pressure, height and diastolic blood pressure both for boys and girls along with correlation between skin fold thickness in relation to body mass index in various socioecomic groups for both boys and girls.

\section{Results and Analysis}

In our study the mean systolic blood pressure in the present study reveals that mean systolic blood pressure in boys increased from $102.75 \pm 3.24 \mathrm{~mm} \mathrm{Hg}$ at 12 years of age to $105.85 \pm 3.58 \mathrm{~mm} \mathrm{Hg}$ at 16 years (table no. 1). In girls mean systolic blood pressure increased from $102.04 \pm 2.53 \mathrm{~mm} \mathrm{Hg}$ at 12 years to $106.48 \pm 3.59 \mathrm{~mm} \mathrm{Hg}$ at 16 years (table no. 2).

The mean diastolic blood pressure increased from $66.85 \pm 3.45 \mathrm{~mm} \mathrm{Hg}$ at 12 years of age to $67.95 \pm 4.24 \mathrm{~mm} \mathrm{Hg}$ at 16 years, in boys (table no. 3). In girls the mean diastolic blood pressure increased from $66.90 \pm 3.38 \mathrm{~mm} \mathrm{Hg}$ at $12 \mathrm{years}$ to 
$68.95 \pm 4.53 \mathrm{~mm} \mathrm{Hg}$ at 16 years (table no. 4). Blood pressure recordings showed an increasing trend steadily with age in the present study. The mean blood pressure when correlated between the boys group and girls there was no statistically significant difference in the mean systolic as well as diastolic pressure between the two sexes (Table no.5).

Table No 1: Observation of Systolic Blood Pressure in Boys

\begin{tabular}{|c|c|c|c|c|c|c|c|c|c|c|}
\hline \multirow{2}{*}{$\begin{array}{l}\text { Age in } \\
\text { years }\end{array}$} & \multirow[b]{2}{*}{$\mathbf{N}$} & \multirow{2}{*}{$\begin{array}{l}\text { Mean } \pm \text { SD } \\
(\mathrm{mm} \mathrm{Hg})\end{array}$} & \multicolumn{7}{|c|}{ Percentiles (mm Hg) } & \multirow{2}{*}{$\begin{array}{l}\text { Range } \\
\text { Min-Max } \\
(\mathrm{mm} \text { Hg) }\end{array}$} \\
\hline & & & $5^{\text {th }}$ & $10^{\text {th }}$ & $25^{\text {th }}$ & $50^{\text {th }}$ & $75^{\text {th }}$ & $90^{\text {th }}$ & $95^{\text {th }}$ & \\
\hline 12 & 200 & $102.75 \pm 3.24$ & 101 & 102 & 104 & 106 & 108 & 109 & 110 & $98-106$ \\
\hline 13 & 200 & $103.81 \pm 2.31$ & 104 & 105 & 106 & 108 & 110 & 111 & 112 & $100-114$ \\
\hline 14 & 200 & $104.93 \pm 3.31$ & 106 & 107 & 109 & 111 & 113 & 114 & 115 & $100-116$ \\
\hline 15 & 200 & $105.82 \pm 3.19$ & 109 & 110 & 112 & 113 & 115 & 117 & 117 & $100-118$ \\
\hline 16 & 200 & $105.85 \pm 3.58$ & 111 & 112 & 114 & 116 & 118 & 119 & 120 & $100-120$ \\
\hline
\end{tabular}

Table No. 2: Observation of Systolic Blood Pressure in Girls

\begin{tabular}{|c|c|c|c|c|c|c|c|c|c|c|}
\hline \multirow{2}{*}{$\begin{array}{l}\text { Age in } \\
\text { years }\end{array}$} & \multirow[b]{2}{*}{$\mathbf{N}$} & \multirow{2}{*}{$\begin{array}{l}\text { Mean } \pm \text { SD } \\
(\mathrm{mm} \mathrm{Hg})\end{array}$} & \multicolumn{7}{|c|}{ Percentiles (mm Hg) } & \multirow{2}{*}{$\begin{array}{l}\text { Range } \\
\text { Min-Max } \\
\text { (mm Hg) }\end{array}$} \\
\hline & & & $5^{\text {th }}$ & $10^{\text {th }}$ & $25^{\text {th }}$ & $50^{\text {th }}$ & $75^{\text {th }}$ & $90^{\text {th }}$ & $95^{\text {th }}$ & \\
\hline 12 & 200 & $102.04 \pm 2.53$ & 102 & 103 & 104 & 105 & 107 & 108 & 109 & $98-108$ \\
\hline 13 & 200 & $104.72 \pm 3.40$ & 104 & 105 & 106 & 107 & 109 & 110 & 110 & $100-110$ \\
\hline 14 & 200 & $104.98 \pm 2.96$ & 106 & 106 & 107 & 109 & 110 & 111 & 112 & $100-114$ \\
\hline 15 & 200 & $105.75 \pm 3.37$ & 107 & 108 & 109 & 110 & 111 & 113 & 113 & $100-116$ \\
\hline 16 & 200 & $106.48 \pm 3.59$ & 108 & 108 & 110 & 111 & 112 & 114 & 114 & $100-120$ \\
\hline
\end{tabular}

Table No. 3: Observation of Diastolic Blood Pressure in Boys

\begin{tabular}{|c|c|c|c|c|c|c|c|c|c|c|}
\hline \multirow{2}{*}{$\begin{array}{l}\text { Age in } \\
\text { years }\end{array}$} & \multirow[b]{2}{*}{$\mathbf{n}$} & \multirow{2}{*}{$\begin{array}{l}\text { Mean } \pm \text { SD } \\
(\mathrm{mm} \mathrm{Hg})\end{array}$} & \multicolumn{7}{|c|}{ Percentiles (mm Hg) } & \multirow{2}{*}{$\begin{array}{l}\text { Range } \\
\text { Min-Max } \\
\text { (mm Hg) }\end{array}$} \\
\hline & & & $5^{\text {th }}$ & $10^{\text {th }}$ & $25^{\text {th }}$ & $50^{\text {th }}$ & $75^{\text {th }}$ & $90^{\text {th }}$ & $95^{\text {th }}$ & \\
\hline 12 & 200 & $66.85 \pm 3.45$ & 64 & 64 & 66 & 68 & 70 & 72 & 74 & $62-72$ \\
\hline 13 & 200 & $67.05 \pm 3.45$ & 65 & 65 & 66 & 68 & 70 & 72 & 75 & $60-74$ \\
\hline 14 & 200 & $67.49 \pm 4.42$ & 65 & 66 & 67 & 69 & 71 & 73 & 76 & $56-78$ \\
\hline 15 & 200 & $67.54 \pm 4.51$ & 66 & 67 & 68 & 69 & 71 & 74 & 78 & $60-78$ \\
\hline 16 & 200 & $67.95 \pm 4.24$ & 68 & 69 & 70 & 72 & 74 & 77 & 79 & $62-78$ \\
\hline
\end{tabular}

Table No. 4: Observation of Diastolic Blood Pressure in Girls

\begin{tabular}{|c|c|c|c|c|c|c|c|c|c|c|}
\hline \multirow{2}{*}{$\begin{array}{l}\text { Age in } \\
\text { years }\end{array}$} & \multirow[b]{2}{*}{$\mathbf{n}$} & \multirow{2}{*}{$\begin{array}{l}\text { Mean } \pm \text { SD } \\
(\mathrm{mm} \mathrm{Hg})\end{array}$} & \multicolumn{7}{|c|}{ Percentiles (mm Hg) } & \multirow{2}{*}{$\begin{array}{l}\text { Range } \\
\text { Min-Max } \\
\text { (mm Hg) }\end{array}$} \\
\hline & & & $5^{\text {th }}$ & $10^{\text {th }}$ & $25^{\text {th }}$ & $50^{\text {th }}$ & $75^{\text {th }}$ & $90^{\text {th }}$ & $95^{\text {th }}$ & \\
\hline 12 & 200 & $66.90 \pm 3.38$ & 62 & 62 & 66 & 68 & 70 & 72 & 74 & $60-74$ \\
\hline 13 & 200 & $67.91 \pm 4.22$ & 64 & 64 & 66 & 69 & 71 & 73 & 75 & $60-80$ \\
\hline 14 & 200 & $68.01 \pm 4.42$ & 66 & 68 & 70 & 72 & 74 & 76 & 78 & $60-78$ \\
\hline 15 & 200 & $68.82 \pm 4.44$ & 68 & 69 & 71 & 73 & 75 & 77 & 80 & $62-78$ \\
\hline 16 & 200 & $68.95 \pm 4.53$ & 68 & 70 & 72 & 74 & 76 & 78 & 81 & $58-78$ \\
\hline
\end{tabular}


Table No. 5: Comparison of Systolic blood pressure between boys and girls

\begin{tabular}{|c|c|c|c|c|c|c|c|c|}
\hline \multirow[b]{2}{*}{$\begin{array}{l}\text { Age in } \\
\text { years }\end{array}$} & \multicolumn{4}{|c|}{ Systolic Pressure } & \multicolumn{4}{|c|}{ Diastolic pressure } \\
\hline & $\begin{array}{c}\text { Boys Mean } \\
\pm \text { SD (mm } \\
\text { Hg) }\end{array}$ & $\begin{array}{c}\text { Girls } \\
\text { Mean } \pm \\
\text { SD }(\mathbf{m m} \\
\text { Hg) }\end{array}$ & Test & Inference & $\begin{array}{c}\text { Boys Mean } \\
\pm \text { SD }(\mathrm{mm} \\
\text { Hg) }\end{array}$ & $\begin{array}{c}\text { Girls } \\
\text { Mean } \pm \\
\text { SD }(\mathbf{m m} \\
\text { Hg) }\end{array}$ & Test & Inference \\
\hline 12 & $\begin{array}{c}102.75 \pm \\
3.24\end{array}$ & $\begin{array}{c}102.04 \pm \\
2.53\end{array}$ & 1.21 & $P>0.05$ & $\begin{array}{c}66.85 \pm \\
3.45\end{array}$ & $\begin{array}{c}66.90 \pm \\
3.38\end{array}$ & 0.41 & $P>0.05$ \\
\hline 13 & $\begin{array}{c}103.81 \pm \\
2.31\end{array}$ & $\begin{array}{c}104.72 \pm \\
3.40\end{array}$ & 1.03 & $\mathrm{P}>0.05$ & $\begin{array}{c}67.05 \pm \\
3.45\end{array}$ & $\begin{array}{c}67.91 \pm \\
4.22\end{array}$ & 1.05 & $P>0.05$ \\
\hline 14 & $\begin{array}{c}104.93 \pm \\
3.31\end{array}$ & $\begin{array}{c}104.98 \pm \\
2.96\end{array}$ & 0.67 & $P>0.05$ & $\begin{array}{c}67.49 \pm \\
4.42\end{array}$ & $\begin{array}{c}68.01 \pm \\
4.42\end{array}$ & 0.46 & $\mathrm{P}>0.05$ \\
\hline 15 & $\begin{array}{c}105.82 \pm \\
3.19\end{array}$ & $\begin{array}{c}105.75 \pm \\
3.37\end{array}$ & 0.74 & $P>0.05$ & $\begin{array}{c}67.54 \pm \\
4.51\end{array}$ & $\begin{array}{c}68.82 \pm \\
4.44\end{array}$ & 0.41 & $\mathrm{P}>0.05$ \\
\hline 16 & $\begin{array}{c}105.85 \pm \\
3.58\end{array}$ & $\begin{array}{c}106.48 \pm \\
3.59\end{array}$ & 0.29 & $P>0.05$ & $\begin{array}{c}67.95 \pm \\
4.24\end{array}$ & $\begin{array}{c}68.95 \pm \\
4.53\end{array}$ & 1.13 & $P>0.05$ \\
\hline
\end{tabular}

Analysis of blood pressure based on weight criteria revealed that the mean systolic pressure in boys steadily increased from $104.8 \mathrm{~mm} \mathrm{Hg}$ in 16-20 kg weight group to $105.6 \mathrm{~mm} \mathrm{Hg}$ in $36-40 \mathrm{~kg}$ weight group. The mean systolic blood pressure in girls increased steadily from $103 \mathrm{~mm} \mathrm{Hg}$ in 16-20 kg weight group to $105.6 \mathrm{~mm} \mathrm{Hg}$ in $36-40 \mathrm{~kg}$ weight group. The mean diastolic blood pressure in boys steadily increased from $67.2 \mathrm{~mm} \mathrm{Hg}$ in $16-20 \mathrm{~kg}$ weight group, to 67.5 $\mathrm{mm} \mathrm{Hg}$ in 36-40 kg weight group. The mean diastolic blood pressure in girls steadily increased from $66.2 \mathrm{~mm} \mathrm{Hg}$ in $16-$ $20 \mathrm{~kg}$ weight group, to $69.1 \mathrm{~mm} \mathrm{Hg}$ in $36-40 \mathrm{~kg}$ weight group. The increase in mean systolic and diastolic blood pressure in both sexes in relation to weight was steady (Table no.6).

Table No. 6: Distribution of blood pressure according to weight

\begin{tabular}{|l|c|c|c|c|c|c|c|c|c|c|}
\hline \multirow{2}{*}{$\begin{array}{l}\text { Weight } \\
(\mathbf{k g s})\end{array}$} & \multicolumn{4}{|c|}{ Boys } & \multicolumn{4}{c|}{ Girls } \\
\cline { 2 - 12 } & $\mathbf{N}$ & \multicolumn{2}{|c|}{$\begin{array}{c}\text { Systolic BP } \\
(\mathbf{m m H g})\end{array}$} & \multicolumn{2}{|c|}{$\begin{array}{c}\text { Diastolic BP (mm } \\
\text { Hg) }\end{array}$} & $\mathbf{N}$ & \multicolumn{2}{c|}{$\begin{array}{c}\text { Systolic BP } \\
(\mathbf{m m} \text { Hg) }\end{array}$} & \multicolumn{2}{c|}{$\begin{array}{c}\text { Diastolic BP } \\
(\mathbf{m m} \text { Hg) }\end{array}$} \\
\hline $16-20$ & 40 & 104.8 & 6.3 & 67.2 & 3.4 & 12 & 103 & 2.9 & 66.2 & 4.5 \\
\hline $21-25$ & 121 & 104.7 & 7.2 & 66.9 & 4.1 & 106 & 104.5 & 2.8 & 66.9 & 3.6 \\
\hline $26-30$ & 203 & 104.2 & 4.5 & 66.9 & 4.0 & 242 & 104.5 & 3.0 & 67.5 & 3.9 \\
\hline $31-35$ & 373 & 105.2 & 4.0 & 67.7 & 4.1 & 367 & 105.6 & 3.4 & 67.6 & 4.5 \\
\hline $36-40$ & 263 & 105.6 & 3.7 & 67.5 & 4.4 & 273 & 105.6 & 3.5 & 69.1 & 4.5 \\
\hline
\end{tabular}

Analysis of blood pressure based on Height criteria revealed the mean systolic pressure in boys steadily increased from $103.08 \mathrm{~mm} \mathrm{Hg}$ in $121-130 \mathrm{~cm}$ height group to $106.05 \mathrm{~mm} \mathrm{Hg}$ in $161-170 \mathrm{~cm}$ height group. The mean systolic blood pressure in girls increased steadily from $104.16 \mathrm{~mm} \mathrm{Hg}$ in $121-130 \mathrm{~cm}$ height group to $105.96 \mathrm{~mm} \mathrm{Hg}$ in $161-170 \mathrm{~cm}$ height group. The mean diastolic blood pressure in boys steadily increased from $66.06 \mathrm{~mm} \mathrm{Hg}$ in $121-130 \mathrm{~cm}$ height group, to $67.43 \mathrm{~mm} \mathrm{Hg}$ in 161-17 cm height group. The mean diastolic blood pressure in girls steadily increased from $66.79 \mathrm{~mm} \mathrm{Hg}$ in $121-130 \mathrm{~cm}$ height group, to $67.97 \mathrm{~mm} \mathrm{Hg}$ in 161-170 $\mathrm{cm}$ height groups. The increase in mean systolic and diastolic blood pressure in both sexes in relation to weight was steady (Table no. 7). 
Table No. 7 Distribution of blood pressure according to Height

\begin{tabular}{|l|c|c|c|c|c|c|c|c|c|c|}
\hline \multirow{2}{*}{$\begin{array}{l}\text { Height (in } \\
\text { cms) }\end{array}$} & \multicolumn{4}{|c|}{ Boys } & \multicolumn{5}{c|}{ Girls } \\
\cline { 2 - 12 } & $\mathbf{N}$ & \multicolumn{2}{|c|}{$\begin{array}{c}\text { Systolic BP } \\
(\mathbf{m m H g})\end{array}$} & \multicolumn{2}{c|}{$\begin{array}{c}\text { Diastolic BP } \\
(\mathbf{m m} \text { Hg) }\end{array}$} & $\mathbf{n}$ & \multicolumn{2}{c|}{$\begin{array}{c}\text { Systolic BP (mm } \\
\text { Hg) }\end{array}$} & $\begin{array}{c}\text { Diastolic BP (mm } \\
\text { Hg) }\end{array}$ \\
\hline & & Mean & SD & Mean & SD & & Mean & SD & Mean & SD \\
\hline $101-110$ & 2 & 115 & 24 & 66 & - & - & - & - & - & - \\
\hline $111-120$ & 3 & 100.7 & 2.31 & 70 & 3.46 & - & - & - & - & - \\
\hline $121-130$ & 36 & 103.08 & 6.69 & 66.06 & 5.31 & 98 & 104.16 & 2.64 & 66.79 & 3.37 \\
\hline $131-140$ & 142 & 104.90 & 8.33 & 66.75 & 3.73 & 102 & 103.87 & 2.41 & 67.0 & 3.41 \\
\hline $141-150$ & 180 & 104.32 & 3.76 & 67.05 & 3.70 & 214 & 104.88 & 3.27 & 67.99 & 4.51 \\
\hline $151-160$ & 453 & 105.08 & 3.13 & 67.61 & 4.13 & 402 & 105.59 & 3.7 & 67.71 & 4.42 \\
\hline $161-170$ & 184 & 106.05 & 3.57 & 67.43 & 4.49 & 184 & 105.96 & 3.37 & 67.97 & 4.41 \\
\hline
\end{tabular}

Correlation of Body Mass Index (BMI) with reference to Skin folds thickness measured values at biceps, triceps, subscapularis and suprailiac showed a significant negative correlation as shown in Table No.8

Table No. 8: Correlation of BMI with reference to Skin folds thickness

\begin{tabular}{|c|c|c|}
\hline Skin fold thickness & BMI & Inference \\
\hline Biceps & -0.135 & $\mathrm{P}<0.05$ \\
\hline Triceps & -0.135 & $\mathrm{P}<0.05$ \\
\hline Subscapularis & -0.140 & $\mathrm{P}<0.05$ \\
\hline Suprailiac & -0.140 & $\mathrm{P}<0.05$ \\
\hline
\end{tabular}

The Incidence of Raised Blood Pressure in Boys and Girls in our study was $1.3 \%$. We observed 26 subjects with blood pressure more than $95^{\text {th }}$ percentile of blood pressure but not more than $99^{\text {th }}$ percentile of which $14(1.4 \%)$ were boys and $12(1.2 \%)$ were girls.

\section{Discussion}

In all the studies in India and abroad it has been shown that blood pressure, both systolic and diastolic, gradually increases with age, The findings of the present study regarding mean systolic and mean diastolic pressure are comparable with findings of the study conducted by N.K. Anand and Lalit Tandon [17]. Their findings (systolic blood pressure) of $110 \mathrm{~mm} \mathrm{Hg}$ at 12 years and $117 \mathrm{~mm} \mathrm{Hg}$ at 16 years for boys and $110 \mathrm{~mm} \mathrm{Hg}$ at 12 years and $118 \mathrm{~mm} \mathrm{Hg}$ at 16 years for girls are close to the findings of the present study. Similarly mean diastolic pressures for both boys and girls in the present study and study conducted by N.K. Anand and Lalit Tandon are comparable [17].

The gradual increase in systolic blood pressure observed in the present study between 12 -16 years in both sexes has been supported by other researchers who observed similar rise in systolic blood pressure in both sexes between 12 to 16 years of age [18]. The gradual increase in the blood pressure along with increase in age can be explained by the fact that, the body mass also increases, which is one of the determinants of blood pressure, along with age. The systolic spurt observed in the present study can be accounted by the onset of puberty in both sexes, which results in increase of body weight and height, as a result of increase in muscular tissue in boys and deposition of adipose tissue in girls, which begins around 11 to 12 years and reaches peak levels by 14-15 years of age. The observations of mean diastolic pressure in the present study resemble those of the study conducted by N.K. Anand and Lalit Tandon [17].

In the present study it ranged from $56 \mathrm{~mm} \mathrm{Hg}$ to $78 \mathrm{~mm}$ of $\mathrm{Hg}$ from 12 to 16 years in boys whereas from 58 to $78 \mathrm{~mm}$ of $\mathrm{Hg}$ from 12 to 16 years in girls. In the study conducted by N.K. Anand and Lalit Tandon it ranged from $73 \mathrm{~mm} \mathrm{Hg}$ at 12 years and $77 \mathrm{~mm} \mathrm{Hg}$ at 16 years in boys and $73 \mathrm{~mm} \mathrm{Hg}$ at 12 years and $77 \mathrm{~mm} \mathrm{Hg}$ at 16 years in girls. All the above studies, including present study show, an approximate increase of diastolic blood pressure by $1 \mathrm{~mm} \mathrm{Hg}$ per year of age. 
It can be observed from the tables mentioned in above discussion, that the blood pressure levels in the present study were considerably lower, both systolic and diastolic pressures, in either sex than the findings in other Indian studies. Even in the Western studies similar differences have been observed, the difference between NIH Task Force readings and Bogalusa heart study being 10-15 mm Hg, with considerably higher level reported in the NIH report [19, 20]. These marked differences are very likely related to methodology, even though the observations are on different populations.

The mean systolic and mean diastolic blood pressures increase steadily and proportionately with weight. This finding is in agreement with that of Agarwal VK et al who found that both systolic and diastolic blood pressures increased with increase in weight [18]. Rakesh Agarwal, et al observed that blood pressure is directly proportional to the ratio of weight/height $(\mathrm{kg} / \mathrm{cm})$ [21]. Sachdev [22] found direct correlation between blood pressure and body weight and Londe found that systolic pressure is related to weight, but not diastolic pressure in either sex. In the Bogalusa heart study, a close relationship (linear relationship) was found between the log of the body weight and blood pressure [19,20]. The mean systolic and mean diastolic blood pressures observed in the present study are lower than that of V.K. Agarwal et al in the comparable weight group [18]. This difference suggests that factors other than body weight, such as height, dietary habits, physical activities, geographical locality may be playing a role in the determination of blood pressure.

The mean systolic blood pressure and mean diastolic blood pressure were found to increase with increase in the body height in both sexes. D. Laroia et al noted similar correlation between height and systolic and diastolic blood pressures in both sexes in the study conducted in 1989 [23]. In contrast to our study V.K. Agarwal et al did not find any correlation between systolic and diastolic blood pressure with height $[18,22]$.

Londe after similar analysis came to conclusion that systolic pressure is probably related to weight, but not to the height in both sexes and the diastolic pressure is not related to either weight or height [24]. Berenson comments that in youth, blood pressure levels vary considerably with height and weight and when children are grouped by body weight and height the usual positive correlation with age is lacking [25].

Voors et al. observed that after adjusting for effects of height and weight on blood pressure levels, age appears to have no relationship to levels. He also comments that approximately $40 \%$ of variability of blood pressure level seems to be explained by a combination of factors such as height, weight, triceps skin fold thickness, or arm circumference [20]. The findings of the present study are in agreement with the statement that height and weight are the strongest determinants of blood pressure.

Prevalence of Hypertension: In the present study the prevalence of hypertension was found to be $1.3 \%$ ( $95^{\text {th }}$ percentile for age and sex was cut-off point).Other workers reported a wide range of figures.

\begin{tabular}{|l|l|}
\hline Percentage prevalence of hypertension as reported by various workers & $0.46 \%$ \\
\hline Anand N.K. and Lalit Tandon (1996) [17] & $1.8 \%$ \\
\hline Agarwal V.K., Rajiv Sharan, Shrivastava AK and Pandey CM (1983) [18] & $2.6 \%$ \\
\hline Rakesh Agarwal, SL Mandowara, B. Bhandari and Garg OP (1982) [21] & $0.54 \%$ \\
\hline Sachdev (1984) [22] & $2.93 \%$ \\
\hline Laroia, M Sharma, V. Diwedi, KM Belapurkar and PS Mathur (1989) [23] & $2.3 \%$ \\
\hline Londe (1971) [26] & $1.3 \%$ \\
\hline Present study & \\
\hline
\end{tabular}

The true incidence of hypertension among children and young adolescents remains unclear. Some workers consider a child as hypertensive if his/her blood pressure is more than two standard deviations above the mean for his/her age on one or more occasions [27]. Various authors have claimed that $1-11.5 \%$ of children will have mild elevation of blood pressure [28].

But the true incidence lies between 1 to 3\% [29]. The vast majority of these children will have mild elevation of blood pressure and labeled as essential hypertensive's [30]. The observation of the present study are in agreement with the above statement as all the 26 children who were labeled as raised blood pressure had only mildly elevated blood pressure 
and none had severe elevation of blood pressure $\left(>99^{\text {th }}\right.$ percentile). The prevalence of hypertension in the present study $(1.3 \%)$ was comparable to most of the studies conducted in India and abroad.

\section{Conclusion}

Blood pressure, both systolic and diastolic gradually increases with age, the increase being more pronounced in systolic blood pressure than in diastolic blood pressure. There is no significant difference in blood pressures of the two sexes. There is a strong correlation between systolic blood pressure and weight and systolic blood pressure and height in both sexes. The prevalence of hypertension in the present study is within the range reported by various workers in the field, in India and abroad. Majority of the children who were labeled as hypertensive's are likely to be suffering from essential hypertension, because of the asymptomatic nature of their condition.

\section{References}

1. Health needs of adolescents. Report of a WHO Expert Committee. World Health Organ Tech Rep Ser. 1977;(609):1-55.

2. Use and interpretation of anthropometric indicators of nutritional status. WHO Working Group. Bull World Health Organ. 1986;64(6):92941.

3. Ke-You G, Da-Wei F. The magnitude and trends of under- and over-nutrition in Asian countries. Biomed Environ Sci. 2001 Jun;14(1-2):53-60.

4. Sawaya AL, Dallal G, Solymos G, de Sousa MH, Ventura ML, Roberts SB, Sigulem DM. Obesity and malnutrition in a Shantytown population in the city of São Paulo, Brazil. Obes Res. 1995 Sep;3 Suppl $2: 107 \mathrm{~s}-115 \mathrm{~s}$

5. Griffiths PL, Bentley ME. The nutrition transition is underway in India. J Nutr. 2001 Oct;131(10):2692-700.

6. Smoak CG, Burke GL, Webber LS, Harsha DW, Srinivasan SR, Berenson GS. Relation of obesity to clustering of cardiovascular disease risk factors in children and young adults. The Bogalusa Heart Study. Am J Epidemiol. 1987 Mar;125(3):364-72.

7. Must A, Jacques PF, Dallal GE, Bajema CJ, Dietz WH. Long-term morbidity and mortality of overweight adolescents. A follow-up of the Harvard Growth Study of 1922 to 1935. N Engl J Med. 1992 Nov 5;327(19):1350-5.
8. Physical status: the use and interpretation of anthropometry. Report of a WHO Expert Committee. World Health Organ Tech Rep Ser. 1995;854:1-452.

9. Biron P, Mongeau JG. Familial aggregation of blood pressure and its components. Pediatr Clin North Am. 1978 Feb;25(1):29-33.

10. Loggie JMH, Editorial, Symposium on pediatric hypertension, Paediatrics Clinics of North America, 1978, p. 25.

11. Kelishadi R, Hashemipour M, Bashardoost N. Blood pressure in children of hypertensive and normotensive parents. Indian Pediatr. 2004 Jan;41(1):73-7.

12. Hurst, The Heart, Volume 2, 10th Edition, 2001, Chapter 51, pp. 1587-88.

13. Chadha SL, Tandon R, Shekhawat S, Gopinath N. An epidemiological study of blood pressure in school children (5-14 years) in Delhi. Indian Heart J. 1999 Mar-Apr;51(2):178-82.

14. Nelson's Textbook of Pediatrics, $17^{\text {th }}$ Edition, Treatment of Hypertension, 2004. p. 1596.

15. Moss AJ. Indirect methods of blood pressure measurement. Pediatr Clin North Am. 1978 Feb;25(1):3-14.

16. Albert R. Rocchini, 1984 December, Childhood hypertension etiology, Diagnosis and treatment, Paediatrics Clinics of North America, December 1984, 31(6):15 25 .

17. Anand NK and Lalit Tandoon, Prevalence of hypertension in school going children, Indian Journal of Paediatrics, 1996, 33, 377-391.

18. Agarwal VK, Sharan R, Srivastava AK, Kumar $\mathrm{P}$, Pandey CM. Blood pressure profile in children of age 3-15 years. Indian Pediatr. 1983 Dec;20(12):921-5.

19. Foster TA, Voors AW, Webber LS, Frerichs RR, Berenson GS. Anthropometric and maturation measurements of children, ages 5 to 14 years, in a 
biracial community--the Bogalusa Heart Study. Am J Clin Nutr. 1977 Apr;30(4):582-91.

20. Voors AW, Webber LS, Berenson GS. Epidemiology of essential hypertension in youth-implications for clinical practice. Pediatr Clin North Am. 1978 Feb;25(1):15-27.

21. Agarwal R, Mandowara SL, Bhandari B, Garg OP. II. Prevalence of hypertension in apparently healthy school children. Indian Pediatr. 1982 Sep;19(9):779-84.

22. Sachdev Y. Normal blood pressure and hypertension in Indian children. Indian Pediatr. 1984 Jan;21(1):41-8.

23. Laroia D, Sharma M, Diwedi V, Belapurkar KM, Mathur PS. Profile of blood pressure in normal school children. Indian Pediatr. 1989 Jun;26(6):531-6.

24. Londe S, Gollub SW, Goldring D. Blood pressure in black and in white children. J Pediatr. 1977 Jan;90(1):93-5.
25. Berenson GS, Cresanta JL, Webber LS. High blood pressure in the young. Annu Rev Med. 1984;35:535-60.

26. Londe S, Bourgoignie JJ, Robson AM, Goldring D. Hypertension in apparently normal children. J Pediatr. 1971 Apr;78(4):569-77.

27. Blaufox MD. Systemic arterial hypertension in pediatric practice. Pediatr Clin North Am. 1971 May;18(2):577-93.

28. Loggie JM, Rauh LW. Persistent systemic hypertension in the adolescent. Med Clin North Am. 1975 Nov;59(6):1371-83.

29. Park JK and Park K (Eds), Textbook of Preventive and Social Medicine, $17^{\text {th }}$ Edition, 2002.

30. Dhillon MJ, Modern management of hypertension, Recent Advances in Pediatrics, Churchill Livingstone, 1984 , p. 35.

\section{How to cite this article?}

Pranam G M, Usha Pranam G, Manjunath G A. Prevalence of hypertension among adolescents. Pediatr Rev: Int J Pediatr Res 2015;2(4):152-159.doi:10.17511/ijpr.2015.i04.21 